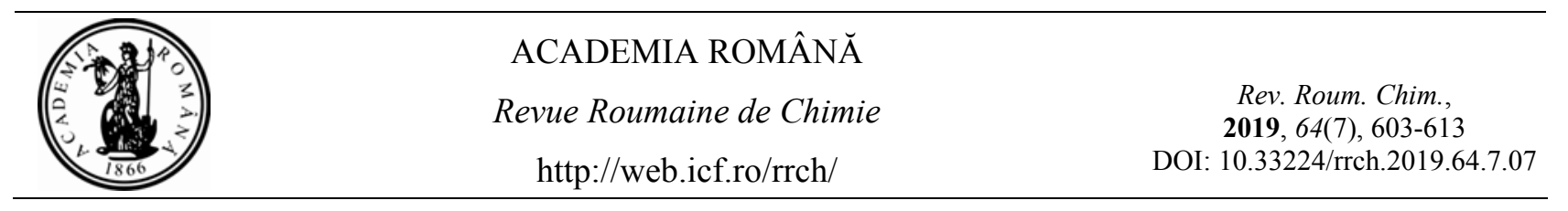

\title{
PEACH STONES VALORIZATED TO HIGH EFFICIENT BIOSORBENT FOR HEXAVALENT CHROMIUM REMOVAL FROM AQUEOUS SOLUTION: ADSORPTION KINETICS, EQUILIBRIUM AND THERMODYNAMIC STUDIES
}

\author{
Fariza KHEMMARI* and Khaled BENRACHEDI \\ Food Technology Laboratory, Environmental Engineering Department, Faculty of Engineering Sciences, \\ M'hamed Bougara University, Boumerdes 35000 (Algeria)
}

Received March 1, 2018

\begin{abstract}
In the last years, much attention has been focused on the use of low-cost adsorbents for the removal of heavy metals from wastewater. Raw biosorbent waste is a cheap and environmentally friendly material that provides good cost-benefit for the industries that use it. The objective of this study is to improve the feasibility of raw local peach stones (RPS) waste for the removal of hexavalent chromium from aqueous solution. The characterization of this raw biomaterial has been performed using various analytical techniques such as FTIR, SEM and XRD. In batch adsorption experiments the adsorption parameters optimized were $\mathrm{pH} 2$, adsorbent dose $4 \mathrm{~g} / \mathrm{L}$, equilibrium contact time $240 \mathrm{~min}$, initial $\mathrm{Cr}(\mathrm{VI})$ concentration $30 \mathrm{mg} / \mathrm{L}$ and temperature $30^{\circ} \mathrm{C}$. The removal percentage of $\mathrm{Cr}(\mathrm{VI})$ was $97 \%$ at $\mathrm{pH}$ 2.The adsorption equilibrium was well explained by the Freundlich isotherm and the process followed the pseudo-second order kinetics. Thermodynamic parameters specify the spontaneous and endothermic nature of biosorption process. Desorption study was carried out with $\mathrm{NaOH}(0.1,0.5$, and $1 \mathrm{M})$ solutions. Investigations carried out proved that RPS is a good potential and ecofriendly biosorbent for the treatment of toxic hexavalent chromium in aqueous solutions.
\end{abstract}



\section{INTRODUCTION}

Rapid increases in industrial progress consequently resulted in adverse pollution effects on the natural environment. ${ }^{1}$ The industrial discharges without any appropriate treatment containing heavy metals represents a significant and long-term environmental hazard. ${ }^{2}$ Heavy metals are nonbiodegradable, and probably may accumulate in microorganisms, aquatic flora and fauna, which in turn may enter into the human food chain and result in significant danger to human health. ${ }^{3}$

Chromium, one of the most highly toxic heavy metal pollutants in wastewaters, is widely used in a variety of industries, such as pharmacy, electro- plating, tanning, metallurgy, battery, textile and catalyst synthesis. ${ }^{4,5}$ Chromium exists in two oxidation states, hexavalent $\mathrm{Cr}(\mathrm{VI})$, and trivalent $\mathrm{Cr}(\mathrm{III})$ and the toxicity of chromium depends upon its oxidation state. ${ }^{6}$ Therefore, due to its high toxicity it is necessary to reduce $\mathrm{Cr}(\mathrm{VI})$ to acceptable levels before discharging it into the environments. The maximum concentration limit set by World Health Organization (WHO) for hexavalent chromium for discharge to surface waters is $0.1 \mathrm{mg} / \mathrm{L}$ and, in potable water, it is $0.05 \mathrm{mg} / \mathrm{L} .^{7}$ Different techniques have been used to reduce the $\mathrm{Cr}$ (VI) concentration of the industrial wastewater to the permissible level, such as chemical precipitation, ion exchange, reduction,

\footnotetext{
${ }^{*}$ Corresponding author: chemmary@yahoo.fr
} 
electrochemical precipitation, solvent extraction, electrodialysis and adsorption. ${ }^{8,9}$ However, high chemical and energy requirement, generation of toxic by-products and incomplete removal limits the wide applicability of these treatment techniques. ${ }^{10}$ The biosorption technique is the most preferred methods to remove heavy metals due to its high efficiency and low cost, ${ }^{11}$ it is considered an interesting alternative to operate mainly using economical and eco-friendly biomaterials. ${ }^{12}$ In recent years, special attention has been focused towards valorization of many agricultural or industrial wastes for their uses in adsorption treatment. These wastes can be used raw ${ }^{13}$ or treated (physically or chemically). ${ }^{14}$ Agricultural by-products exist in large amounts, which represent consequently a solid pollutant to the environment. In recent years, peach stones have been used raw $^{15}$ or treated ${ }^{16}$ for the removal of heavy metals and organic pollutants from aqueous solution. This study deals with the biosorption ability of raw peach stones for the removal of chromium from synthetic aqueous solutions and the possibility of regenerating the adsorbent and metal recovery.

\section{EXPERIMENTAL}

\section{Preparation and characterization of biosorbent (RPS)}

The adsorbent used in this study was prepared from agricultural waste biomass: peach stones. The collected raw peach stones, were first washed several times with tap water to remove the adhering impurities followed by distilled water, after drying in an oven at $110^{\circ} \mathrm{C}$ for $24 \mathrm{~h}$ they were crushed and sieved to desired particle size $(0.315-1 \mathrm{~mm})$, finally, the resulting material obtained without any physical or chemical treatment was named as RPS and stored in a desiccator for use in adsorption studies. The characterization of the prepared adsorbent (RPS) is an important factor to explain the mechanism of biosorption process for removal of $\mathrm{Cr}(\mathrm{VI})$ from aqueous solutions. Different techniques were used for the adsorbent characterization. The functional groups at the surface of the adsorbent were analysed before and after adsorption using Fourier Transform Infrared spectroscopy (Bruker ALPHA) at wavelengths in the range $400-4000 \mathrm{~cm}^{-1}$. The morphology of the adsorbent was determinated by scanning electron microscope (SEM). The crystallinity or amorphous structure of the used adsorbent was determined by X-ray diffractometer (XRD, Philips XPERT PRO) with CuKa radiation $\left(\lambda=1.54 \mathrm{~A}^{\circ}\right)$ generated at $(45 \mathrm{Kv}, 20 \mathrm{~mA})$.

\section{Preparation of $\mathrm{Cr}$ (VI) solution}

A stock synthetic solution of chromium(VI) ions $(1000 \mathrm{mg} / \mathrm{L})$ was prepared by dissolving $2.8269 \mathrm{~g}$ of potassium dichromate $\mathrm{K}_{2} \mathrm{Cr}_{2} \mathrm{O}_{7}$ (BIOCHEM chemopharma) in $1000 \mathrm{~mL}$ of distilled water. Experimental solutions of the desired concentrations were obtained by dilution of the stock solution. The initial $\mathrm{pH}$ of working solutions for biosorption experiments was adjusted to the desired value by adding hydrochloric acid $\mathrm{HCl}$ or sodium hydroxide $\mathrm{NaOH}(0.1 \mathrm{M})$.

\subsection{Batch biosorption experiments}

The adsorbent prepared from raw peach stones was tested for the removal of $\mathrm{Cr}(\mathrm{VI})$ from aqueous solution in batch system. All batch experiments were carried out by mixing a fixed dose of RPS samples with $50 \mathrm{~mL}$ of $\mathrm{Cr}(\mathrm{VI})$ solution in a $100 \mathrm{~mL}$ beakers and agitated on a Heating magnetic-stirrer (IKA R5), for the determination of the optimal conditions on the removal efficiency of $\mathrm{Cr}(\mathrm{VI})$ various experimental parameters, such as $\mathrm{pH}(2-11)$, temperature $\left(10^{\circ} \mathrm{C}-40^{\circ} \mathrm{C}\right)$, adsorbent dose (1-10 g/L), initial Cr(VI) concentration (10$100 \mathrm{mg} / \mathrm{L}$ ), were investigated. After each experiment of adsorption, the solution was filtered and the residual concentration of $\mathrm{Cr}(\mathrm{VI})$ was determined by using spectrophotometer (UV-1800 SHIMADZU) at $\lambda \max 540 \mathrm{~nm}$ after complexing with 1, 5-diphenylcarbazide in acidic medium. ${ }^{17,18}$

The removal percentage (R \%) and the biosorption capacity $\mathrm{q}_{\mathrm{t}}(\mathrm{mg} / \mathrm{g})$ of $\mathrm{Cr}(\mathrm{VI})$ by RPS were calculated using the following equations:

$$
R(\%)=\frac{C_{0}-C_{t}}{C_{0}} \times 100
$$

where $\mathrm{C}_{0}(\mathrm{mg} / \mathrm{L})$ and $\mathrm{C}_{\mathrm{t}}(\mathrm{mg} / \mathrm{L})$ represent the concentrations initially and at time $t$ respectively.

$$
q_{t}=\frac{C_{0}-C_{t}}{m} \times V
$$

where $\mathrm{V}(\mathrm{L})$ is the solution volume, $\mathrm{m}(\mathrm{g})$ represents the mass of adsorbent, and also $\mathrm{C}_{0}(\mathrm{mg} / \mathrm{L})$ and $\mathrm{C}_{\mathrm{t}}(\mathrm{mg} / \mathrm{L})$ are the $\mathrm{Cr}(\mathrm{VI})$ concentrations initially and at time $t$ respectively.

Furthermore, $q_{e}(\mathrm{mg} / \mathrm{g})$ is the amount of chromium adsorbed at equilibrium and is calculated from equation (2) when $t$ is equal to the equilibrium contact time.

\section{Desorption and regeneration of biosorbent}

The desorption processes are important from two points of view: first, to recover the metal ion and its subsequent use in industrial field and, secondly, the reuse of the regenerated sorbent. ${ }^{19}$ The desorption experiments were carried out using the $\mathrm{NaOH}$ desorbing agent at different concentrations $(0.1$, 0.5 , and $1.0 \mathrm{M}$ ) with stirring at $200 \mathrm{rpm}$ for $24 \mathrm{~h}$. After a desorption process, the filtrates were analyzed to determine the $\mathrm{Cr}(\mathrm{VI})$ concentration and the percentage of desorbed $\mathrm{Cr}(\mathrm{VI})$ was calculated using the following expression:

$$
\% \mathrm{Cr}(\mathrm{VI}) \text { desorbed }=\frac{\text { amount }_{\text {des }}}{\text { amount }_{\text {ads }}} \times 100
$$

where amount $_{\text {des }}$ is the amount of $\mathrm{Cr}(\mathrm{VI})$ desorbed and amount $_{\mathrm{ads}}$ is the amount of $\mathrm{Cr}(\mathrm{VI})$ adsorbed.

\section{RESULTS AND DISCUSSION}

\section{Characterization of the RPS biosorbent}

In order to understand the adsorption of $\mathrm{Cr}(\mathrm{VI})$ onto RPS, physicochemical characterization of the adsorbent was carried out. The morphology of the raw peach stones biosorbent presented in Fig. 1 was observed by using scanning electron microscopy (SEM). The representative SEM figures show that 
the external surface of RPS presents irregular porous nature structure. This porosity was formed during the oven-heating step in the preparation of the adsorbent. ${ }^{20}$ Based on the surface morphology results of the RPS, it is suggested that the raw peach stones can be an effective adsorbent.

The crystalling or amorphous nature of the RPS biosorbent was performed by X-ray diffraction analysis (XRD), the spectrum presented in Fig. 2 shows the presence of major peak at $2 \theta=21.9^{\circ}$, corresponding to the (200) crystallographic plane. The XRD result shows characteristic wide reflections of cellulose I (card N0.PDF-2 03-0289). ${ }^{15}$

The FTIR spectrum of the RPS before and after biosorption of chromium illustrated in Fig. 3 shows a number of major absorption bands indicating the surface functional groups of the adsorbent. The main absorption bands were observed at 3440 , $2925,1735,1633,1261$ and $1047 \mathrm{~cm}^{-1}$. The intense absorption band at $3440 \mathrm{~cm}^{-1}$ assigned to $\mathrm{O}-\mathrm{H}$ stretching vibrations of phenol group of cellulose and $\operatorname{lignin}^{21,2}$, the bands at 2854-2925 $\mathrm{cm}^{-1}$ are assigned to asymmetric and symmetric stretching vibrations of $-\mathrm{CH}_{2}$ and $-\mathrm{CH}_{3}$ cellulose groups. ${ }^{22,23}$ The bands at 1735, 1508, 1457, 1420, and 1047 $\mathrm{cm}^{-1}$ are attributed to the stretching vibrations of the aromatic ring stretching $(\mathrm{C}-\mathrm{C}) /(\mathrm{C}=\mathrm{C}){ }^{24,25}$ The band at $1633 \mathrm{~cm}^{-1}$ correspond to the $\mathrm{C}=\mathrm{C}$ stretching vibration of the aromatic ring structures. ${ }^{23}$ However, band at $718 \mathrm{~cm}^{-1}$ is associated to the torsional vibrations of benzene $\mathrm{t}(\mathrm{C}-\mathrm{H}) .{ }^{15}$ The FTIR spectrum of the PS biomass after biosorption is very similar to the spectrum before biosorption.
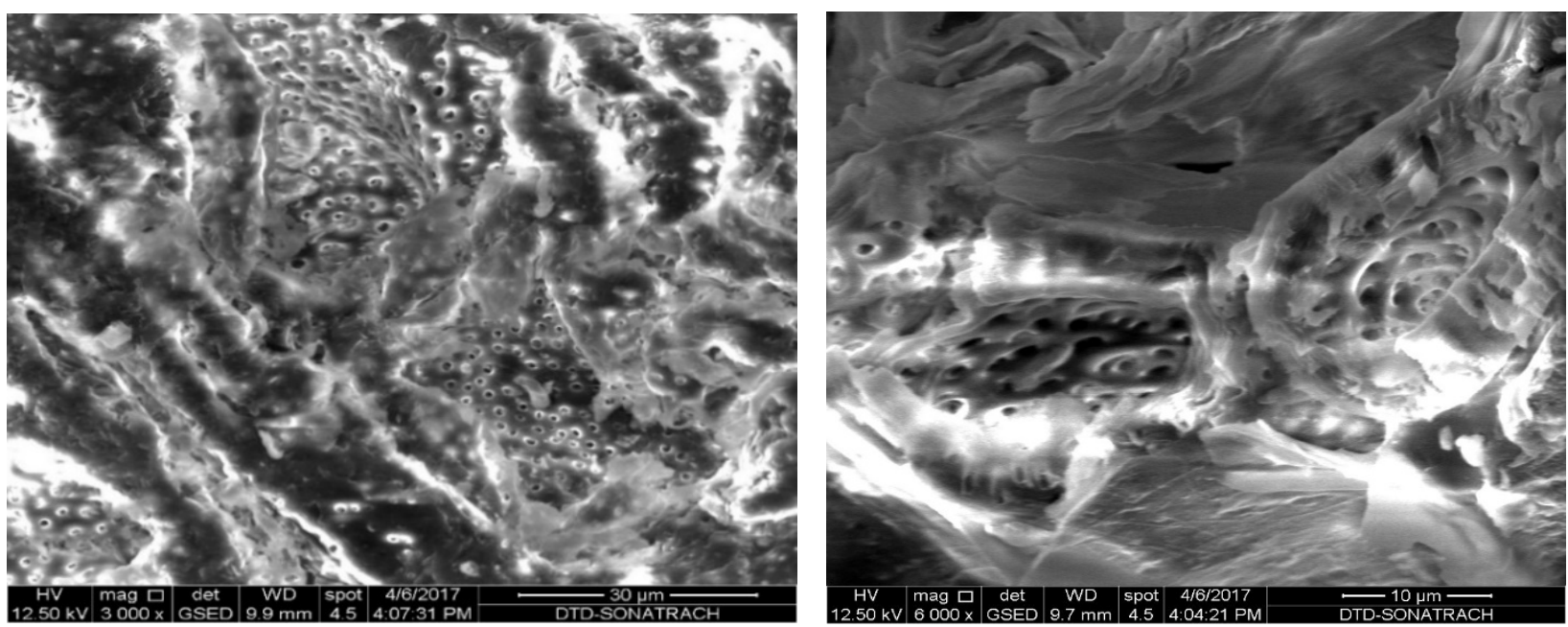

Fig. 1 - SEM images of the raw peach stones adsorbent.



Fig. 2 - XRD pattern of the RPS biosorbent. 


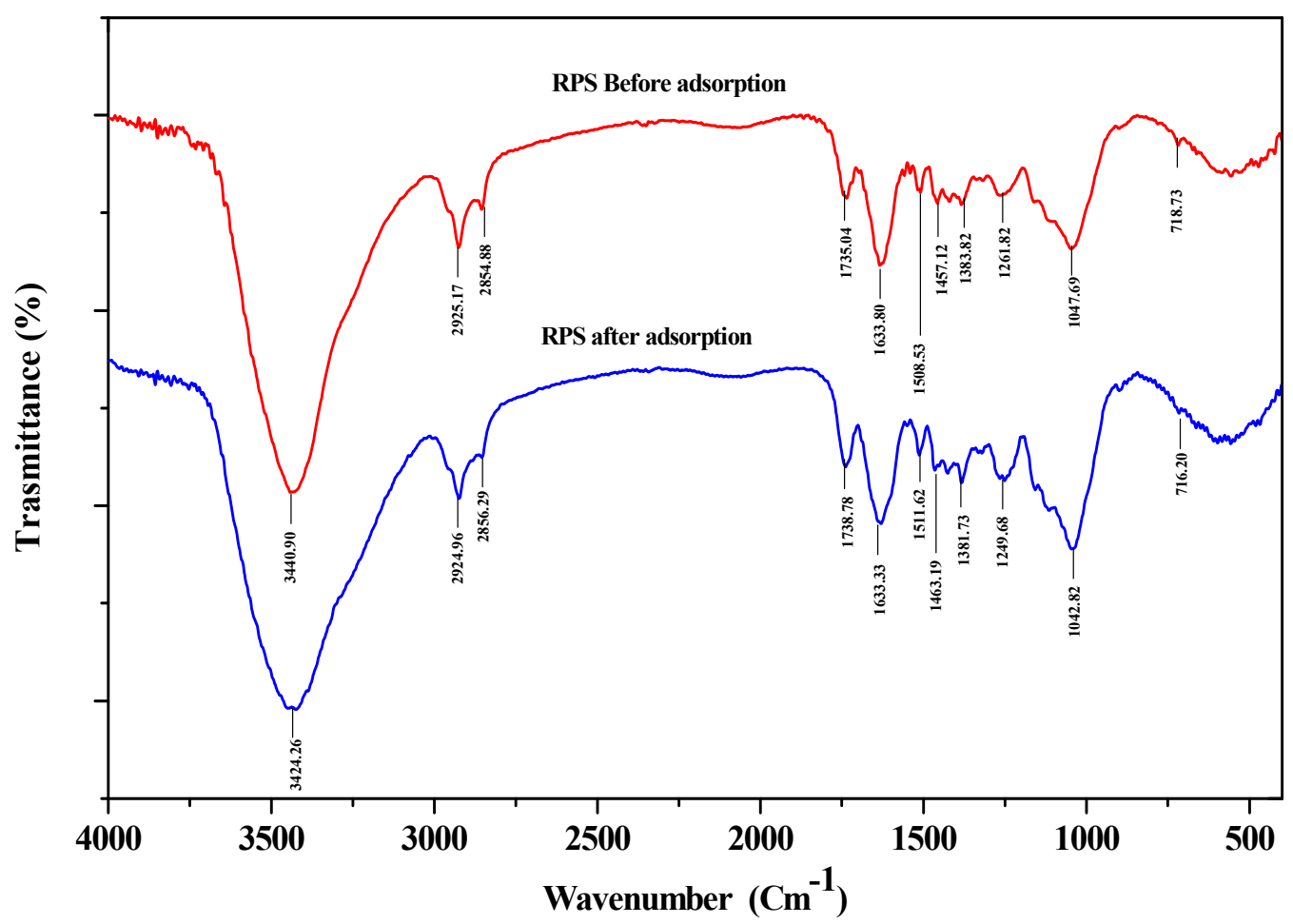

Fig. 3 - FTIR spectra of RPS before and after $\mathrm{Cr}(\mathrm{VI})$ adsorption.

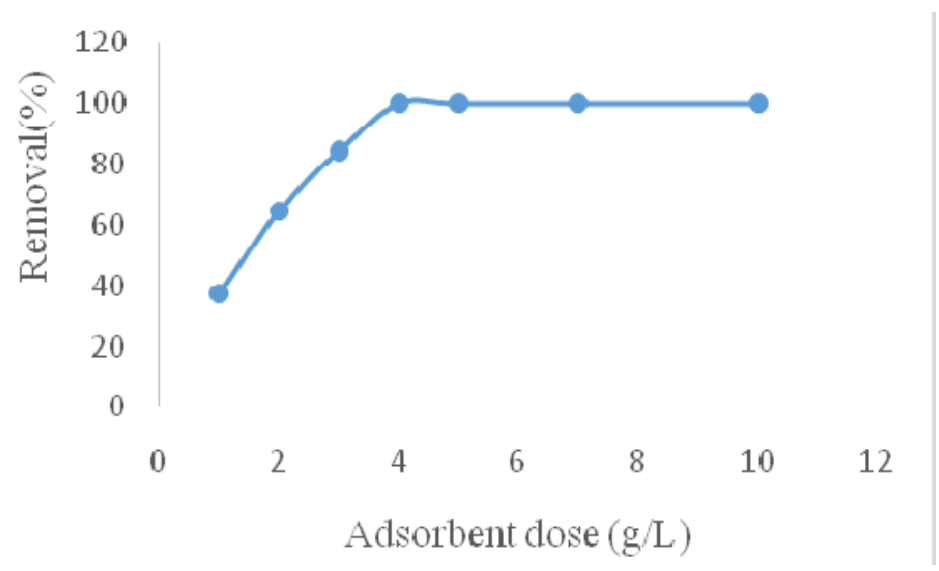

Fig. 4 - Effect of RPS dose on percentage removal of $\mathrm{Cr}(\mathrm{VI})$.

\section{Biosorption process}

\section{Effect of adsorbent dose on Cr(VI) removal}

The effect of biosorbent (RPS) dose on $\mathrm{Cr}(\mathrm{VI})$ adsorption from aqueous solutions was investigated using 1 to $10 \mathrm{~g} / \mathrm{L}$ adsorbent dose at initial $\mathrm{Cr}(\mathrm{VI})$ concentration of $30 \mathrm{mg} / \mathrm{L}$ and $\mathrm{pH}$ of 2.0. The effect of adsorbent dose on $\mathrm{Cr}(\mathrm{VI})$ removal is shown in Fig. 4. Results show that the removal of $\mathrm{Cr}(\mathrm{VI})$ increases with increase in adsorbent (RPS) amounting up to $4 \mathrm{~g} / \mathrm{L}$. The increase in $\mathrm{Cr}(\mathrm{VI})$ percentage removal at higher adsorbent dose may be due to the fact that higher surface area is available for the adsorption process. ${ }^{27}$ The optimal adsorbent dose of $4 \mathrm{~g} / \mathrm{L}$ was selected for further adsorption experiments in this study.

\section{Effect of contact time and initial $\mathrm{Cr}(\mathrm{VI})$ concentration}

The effect of contact time and the initial concentration is very important to assess the reaction kinetics. The effect of contact time on $\mathrm{Cr}(\mathrm{VI})$ removal by RPS was investigated at different initial $\mathrm{Cr}$ (VI) concentrations ranging from 10 to $100 \mathrm{mg} / \mathrm{L}$ at $\mathrm{pH} 2.0$, optimal adsorbent dosage and temperature $30^{\circ} \mathrm{C}$. The adsorption capacity increased with the increase of contact time for all concentrations. An increase in 
adsorption capacity was observed from 2.48 to $17.91 \mathrm{mg} / \mathrm{g}$ with an increase in initial $\mathrm{Cr}(\mathrm{VI})$ concentration from 10 to $100 \mathrm{mg} / \mathrm{L}$ (Fig. 5a). Thus, the adsorption capacity is dependent on contact time and the initial $\mathrm{Cr}(\mathrm{VI})$ concentration. The increase in adsorption capacity of the RPS biosorbent with increasing $\mathrm{Cr}(\mathrm{VI})$ concentration was due to higher probability of collision between $\mathrm{Cr}(\mathrm{VI})$ ions and RPS biosorbent, increased driving force of the concentration gradient. ${ }^{28,29} \mathrm{As}$ is seen in Fig. $5 \mathrm{~b}$, the percentage removal then depended upon the initial concentration. At contact time of $240 \mathrm{~min}$ (Equilibrium time), the percentage removal of $\mathrm{Cr}(\mathrm{VI})$ decreased from $100 \%$ to $71.65 \%$ with an increase of $\mathrm{Cr}(\mathrm{VI})$ concentration from 10 to $100 \mathrm{mg} / \mathrm{L}$. The decline in the $\mathrm{Cr}(\mathrm{VI})$ percentage removal could be explained by the fact that with the increasing concentration, the binding sites of biosorbent are becoming saturated and no additional ions can be adsorbed.

\section{Effect of initial pH solution on Cr (VI) adsorption}

The $\mathrm{pH}$ of the aqueous solution is one of the most important controlling parameter in the chromium biosorption process. It controls the surface properties of the biosorbent and adsorbate speciation. The plot of percentage removal of $\mathrm{Cr}(\mathrm{VI})$ represented in Fig. 6 shown that the Cr(VI) adsorption on RPS was strongly dependent on the initial solution $\mathrm{pH}$. The maximum percentage chromium removal was $97 \%$ at $\mathrm{pH} 2.0$. This could be explained by the fact that $\mathrm{Cr}(\mathrm{VI})$ exists in $\mathrm{HCrO}_{4}^{-}$predominant form at $\mathrm{pH} 2.0$ and the adsorbent surface is also protonated and there is a strong electrostatic attraction between positively charged adsorbent surface and negatively charged $\mathrm{HCrO}_{4}^{-}$. Thereafter, it was observed a drastic decrease in $\mathrm{Cr}$ (VI) adsorption percentage with an increase in $\mathrm{pH}$ solution. At higher $\mathrm{pH}$ the surface of adsorbent becomes negatively charged and also there is abundance of hydroxyl ions in aqueous solution ${ }^{11,6}$ resulting in the repulsive force between $\mathrm{Cr}(\mathrm{VI})$ anions and negatively charged biosorbent surface. Additionally, higher $\mathrm{pH}$ decreasing the removal may be explained by the competitive adsorption between chromate and hydroxyl ions. Therefore, a $\mathrm{pH}$ of 2.0 was taken as the optimum value for the rest of the experiments study and was in accordance with other work in the literature. ${ }^{30,31}$

(a)

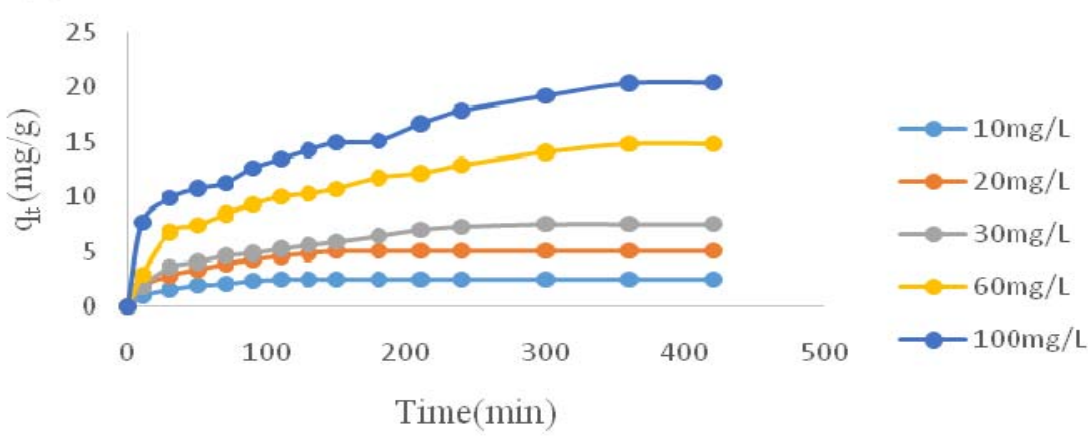

(b)



Fig. 5 - Effect of contact time and initial $\mathrm{Cr}(\mathrm{VI})$ concentration on adsorption capacity (a) and percentage removal (b) of Cr(VI) by RPS. 




Fig. 6 - Effect of $\mathrm{pH}$ on the percentage removal of $\mathrm{Cr}(\mathrm{VI})$ by RPS.

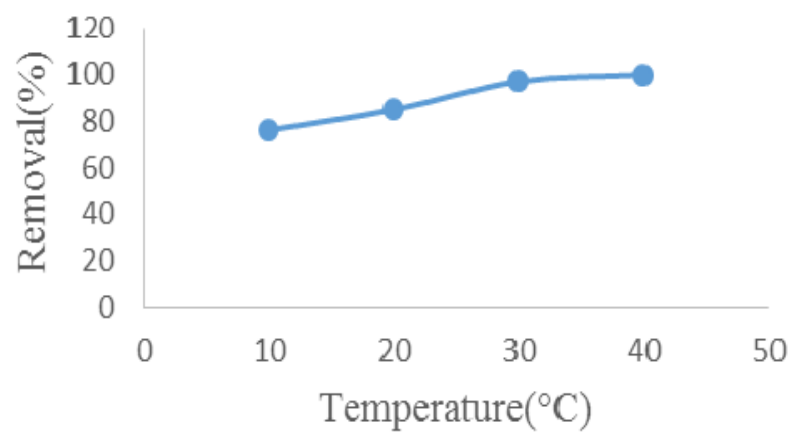

Fig. 7 - Effect of temperature on the removal of $\mathrm{Cr}(\mathrm{VI})$ on RPS.

\section{Effect of temperature}

The effect of temperature on the removal of $\mathrm{Cr}(\mathrm{VI})$ by RPS was studied at four different temperatures $10,20,30$ and $40^{\circ} \mathrm{C}$ at $\mathrm{pH} 2.0$ with initial $\mathrm{Cr}(\mathrm{VI})$ concentration $(30 \mathrm{mg} / \mathrm{L})$. As shown in Fig. 7, chromium sorption percentage increased from 76.15 to $99.93 \%$ for increasing temperatures from 10 to $40^{\circ} \mathrm{C}$. The increase in metal sorption with increase in solution temperature may be due to the increase in diffusion rate of $\mathrm{Cr}(\mathrm{VI})$ ions in the external mass transport process with temperature, ${ }^{32,33}$ and the increase in the number of the adsorption sites generated due to the internal bond breakage near the edge of the adsorbents' active surface sites. ${ }^{34,35}$ The increase in the adsorption with temperature may also explained by the relationship between the kinetic energies of the chromium ion and the active sites of the biosorbent. ${ }^{36,5}$ There is no significant change in adsorption percentage at 30 and $40{ }^{\circ} \mathrm{C}$ and hence, $30{ }^{\circ} \mathrm{C}$ is considered as optimum.

\section{Kinetics of $\mathrm{Cr}(\mathrm{VI})$ adsorption}

The kinetics of adsorption shows the relationship between rates of adsorption with its contact time. Several kinetic models can be used to explain it. In this work the adsorption kinetics of $\mathrm{Cr}(\mathrm{VI})$ on RPS was evaluated using pseudo firstorder $(\mathrm{Eq} \mathrm{4})^{37}$ and pseudo second-order $(\mathrm{Eq} \mathrm{5})^{38}$ models.

\subsection{Pseudo-first order model}

The pseudo-first order kinetic equation is expressed as:

$$
\log \left(\mathrm{q}_{\mathrm{e}}-\mathrm{q}_{\mathrm{t}}\right)=\log \mathrm{q}_{\mathrm{e}}-\frac{\mathrm{k}_{1}}{2.303} \mathrm{t}
$$

In this equation, $\mathrm{q}_{\mathrm{t}}$ is adsorption quantity $(\mathrm{mg} / \mathrm{g})$ at time $\mathrm{t}, \mathrm{q}_{\mathrm{e}}$ is sorption capacity at equilibrium $(\mathrm{mg} / \mathrm{g}), \mathrm{k}_{1}$ is kinetic rate constant for pseudo-first order $\left(\mathrm{min}^{-1}\right)$ and it was calculated from the plot of $\log \left(\mathrm{q}_{\mathrm{e}}-\mathrm{q}_{\mathrm{t}}\right)$ against $\mathrm{t}$.

\subsection{Pseudo-second order model}

The linear form of pseudo-second order kinetic model equation is represented as:

$$
\frac{\mathrm{t}}{\mathrm{q}_{\mathrm{t}}}=\frac{1}{\mathrm{k}_{2} \cdot \mathrm{q}_{\mathrm{e}}^{2}}+\frac{1}{\mathrm{q}_{\mathrm{e}}} \mathrm{t}
$$

where $\mathrm{q}_{\mathrm{e}}$ and $\mathrm{q}_{\mathrm{t}}$ are the amount of $\mathrm{Cr}(\mathrm{VI})$ that was adsorbed $(\mathrm{mg} / \mathrm{g})$ at equilibrium and at time $\mathrm{t}(\mathrm{min})$ respectively, and $\mathrm{k}_{2}$ is the pseudo-second-order 
rate constant of adsorption ( $\mathrm{g} / \mathrm{mg} \mathrm{min})$. The pseudo-second-order rate constants $\mathrm{q}_{\mathrm{e}}$ and $\mathrm{k}_{2}$ were calculated by plotting $t / q_{t}$ versus $t$ at different concentrations of $\mathrm{Cr}(\mathrm{VI})$.

The kinetic modeling of the experimental is shown in Fig. 8. All the obtained kinetic parameters calculated from linear plots and correlation coefficient $\left(\mathrm{R}^{2}\right)$ values were represented in Table 1 . Straight lines were achieved for all the initial concentrations based on the pseudo-first-order and pseudo-second-order models (Fig. 8(a) (b)). On comparison of $\mathrm{R}^{2}$ values, it can be concluded that the adsorption of $\mathrm{Cr}(\mathrm{VI})$ ions onto the RPS followed the pseudo second order kinetic model.

Table 1

Adsorption kinetics parameters of Cr(VI) on RPS

\begin{tabular}{cccccccc}
\hline & & \multicolumn{2}{c}{ Pseudo-first order parameters } & \multicolumn{3}{c}{ Pseudo-second order parameters } \\
\cline { 3 - 7 } $\mathrm{C}_{0}($ & $\begin{array}{c}\mathrm{q}_{\mathrm{e}} \\
\mathrm{mg} / \mathrm{L})\end{array}$ & $\begin{array}{c}\mathrm{q}_{\mathrm{e}} \\
(\mathrm{mg} / \mathrm{g})\end{array}$ & $\begin{array}{c}\mathrm{k}_{1} \\
\left(\mathrm{~min}^{-1}\right)\end{array}$ & $\mathrm{R}^{2}$ & $\mathrm{q}_{\mathrm{e} \mathrm{c}}(\mathrm{mg} / \mathrm{g})$ & $\begin{array}{c}\mathrm{K}_{2} \\
(\mathrm{~g} / \mathrm{mg} . \mathrm{min})\end{array}$ \\
\hline 10 & 2.482 & 3.001 & 0.0387 & 0.9083 & 2.9620 & 0.0134 & 0.9928 \\
20 & 4.919 & 5.300 & 0.0272 & 0.9327 & 5.8893 & 0.0053 & 0.9890 \\
30 & 7.27 & 6.778 & 0.0127 & 0.9236 & 8.4175 & 0.0022 & 0.0011 \\
60 & 13.941 & 11.447 & 0.0094 & 0.9751 & 15.7233 & 0.9863 \\
100 & 21.457 & 16.248 & 2.3092 & 0.9570 & 22.8310 & 0.0007 & 0.9581 \\
\hline
\end{tabular}

(a)

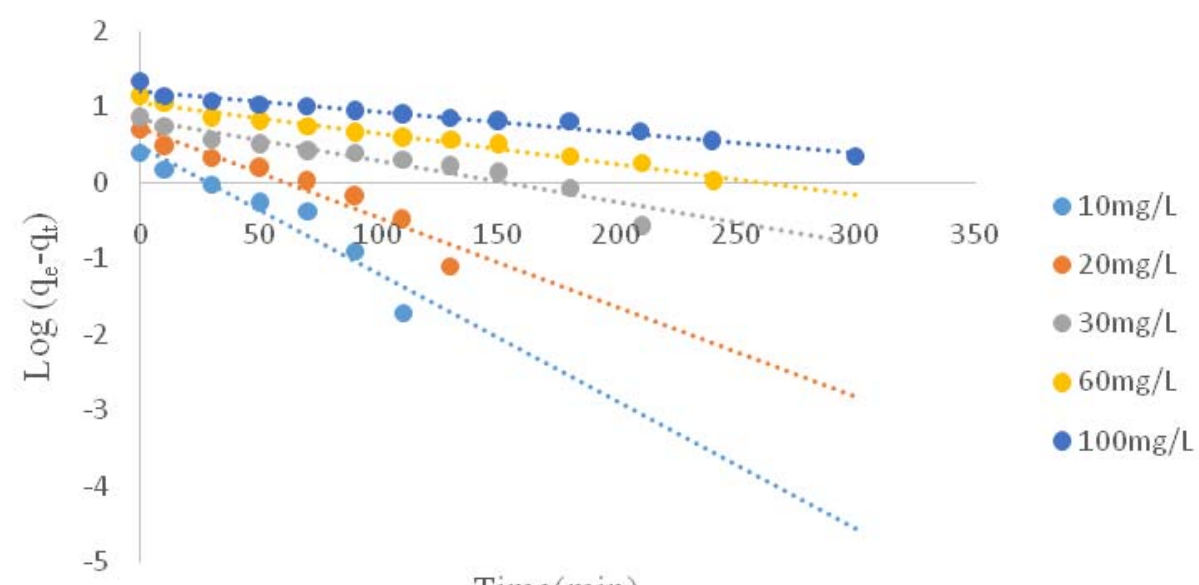

(b)

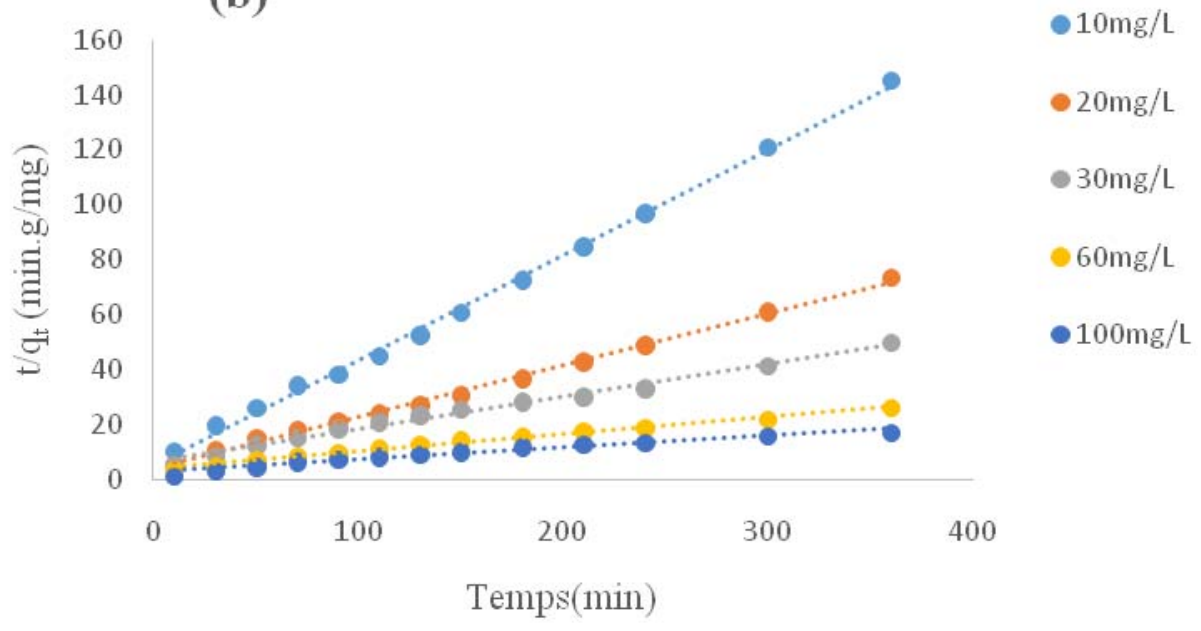

Fig. 8 - Kinetic models for $\mathrm{Cr}(\mathrm{VI})$ adsorption (a) pseudo first order, (b) pseudo second order. 


\section{Biosorption isotherm}

Biosorption isotherm represents the relationship between adsorbed metal ion per unit weight of adsorbent $\left(\mathrm{q}_{\mathrm{e}}\right)$ and residual concentration of metal ion in solution $\left(\mathrm{C}_{\mathrm{e}}\right)$ at equilibrium.

Langmuir and Freundlich isotherm models were applied to investigate the biosorption process of $\mathrm{Cr}(\mathrm{VI})$ on RPS adsorbent at a constant temperature and the different isotherm constants and regression values determined were presented in Table 2 .

\subsection{Langmuir isotherm model}

Langmuir adsorption isotherm model assumed that the uptake of adsorbate molecules occurs on a homogenous surface by monolayer adsorption without any interaction between adsorbed molecules. ${ }^{39,40}$

The Langmuir isotherm model is given by the following equation: ${ }^{41,42}$

$$
\frac{C_{e}}{q_{e}}=\frac{1}{q_{m} \cdot K_{L}}+\frac{C_{e}}{q_{m}}
$$

where, $\mathrm{C}_{\mathrm{e}}(\mathrm{mg} / \mathrm{L})$ is the equilibrium $\mathrm{Cr}(\mathrm{VI})$ concentration, $\mathrm{q}_{\mathrm{e}}(\mathrm{mg} / \mathrm{g})$ is the amount of $\mathrm{Cr}(\mathrm{VI})$ adsorbed at equilibrium, $\mathrm{q}_{\mathrm{m}}(\mathrm{mg} / \mathrm{g})$ is the maximum $\mathrm{Cr}(\mathrm{VI})$ adsorption capacity by the biomaterial and $\mathrm{K}_{\mathrm{L}}$ $(\mathrm{L} / \mathrm{mg})$ is the Langmuir isotherm constant related to energy of adsorption. A plot of $\mathrm{C}_{\mathrm{e}} / \mathrm{q}_{\mathrm{e}}$ versus $\mathrm{C}_{\mathrm{e}}$ gives a straight line of slope $1 / \mathrm{q}_{\mathrm{m}}$ and intercepts $1 /\left(q_{m} \cdot K_{L}\right)$. The essential characteristics of the Langmuir isotherm, dimensionless separation factor $\mathrm{R}_{\mathrm{L}}$, defined by Weber and Chackravorti, ${ }^{43}$ is expressed by the following equation:

$$
R_{L}=\frac{1}{1+K_{L} \cdot C_{0}}
$$

The value of separation factor $R_{L}$ indicate the type of isotherm: favorable $\left(0<\mathrm{R}_{\mathrm{L}}<1\right.$, linear $\left(\mathrm{R}_{\mathrm{L}}=1\right)$ and irreversible $\left(\mathrm{R}_{\mathrm{L}}=0\right)$.

\subsection{Freundlich isotherm model}

The Freundlich model is an empirical equation based on the adsorption of adsorbate onto heterogeneous surface. ${ }^{44,42}$

The linear logarithmic form of the Freundlich equation is expressed by

$$
\log q_{e}=\log K_{F}+\frac{1}{n} \log C_{e}
$$

where $\mathrm{K}_{\mathrm{F}}\left(\mathrm{mg}^{1-1 / n} \mathrm{~L}^{1 / \mathrm{n}} \mathrm{g}^{-1}\right)$ and $\mathrm{n}$ are the Freundlich constants indicating adsorption capacity and intensity.

The graph of $\log q_{e}$ versus $\log C_{e}$ was drawn to determine Freundlich constants $\mathrm{K}_{\mathrm{F}}$ and $\mathrm{n}$.

The plots of isotherms linearized of the Langmuir (a) and Freundlich (b) of $\mathrm{Cr}$ (VI) adsorption on RPS are presented in Fig. 9. From Table 2 , the calculated value for $R_{L}$ was found less than one confirmed favorability of $\mathrm{Cr}(\mathrm{VI})$ biosorption onto RPS under the conditions used in this study. The value of constant $\mathrm{n}$ obtained from the Freundlich isotherm model for RPS was greater than unity, indicated favorable nature of adsorption. The results showed that Freundlich isotherm gave the best fit for the chromium (VI) adsorption by RPS and was confirmed by high $\mathrm{R}^{2}$ value (0.998).

\subsection{Thermodynamic parameters of $\mathrm{Cr}(\mathrm{VI})$ adsorption}

The thermodynamic parameters such as entropy change $(\boldsymbol{\Delta} \mathbf{S})$, enthalpy change $(\boldsymbol{\Delta} \mathbf{H})$ and Gibb's energy $(\boldsymbol{\Delta} \mathbf{G})$ were determined to evaluate the feasibility and nature of $\mathrm{Cr}(\mathrm{VI})$ adsorption by adsorbent, using the following expressions: ${ }^{45}$

$$
\begin{aligned}
\Delta G & =-R T \ln K_{c} \\
\ln K_{c} & =-\frac{\Delta H}{R T}+\frac{\Delta S}{R}
\end{aligned}
$$

where $\mathrm{R}(8.314 \mathrm{~J} / \mathrm{mol} \mathrm{K})$ is the gas constant, $\mathrm{T}(\mathrm{K})$, absolute temperature and $\mathrm{K}_{\mathrm{c}}$ is the equilibrium constant defined by

$$
K_{c}=\frac{C_{0}-C_{e}}{C_{e}}
$$

The values of $\Delta \mathbf{H}$ and $\Delta \mathbf{S}$ were calculated from the plot of $K_{c}$ vs $1 / T$ as shown in Fig. 10.The values of $\Delta \mathbf{H}, \Delta \mathbf{S}$ and $\Delta \mathbf{G}$ for the biosorption of $\mathrm{Cr}(\mathrm{VI})$ onto RPS at various temperatures are listed in Table 3. The positive value of $\mathbf{\Delta H}$ confirmed the endothermic process of adsorption and that an increase in temperature favored the biosorption process. The negative values of $\Delta \mathrm{G}$ show that the adsorption process is feasible and spontaneous. The $\boldsymbol{\Delta} \mathbf{S}$ value is positive, which suggested that the randomness increased at solid- solution interface during the adsorption of $\mathrm{Cr}(\mathrm{VI})$ on the RPS. 


\section{Desorption study}

Desorption experiments was carried out using different concentrations of $\mathrm{NaOH}$ desorbing agent. The percentage of $\mathrm{Cr}(\mathrm{VI})$ desorbed with $0.1,0.5$, and $1 \mathrm{M} \mathrm{NaOH}$ were: $11.91 \%, 45.83 \%$ and 57.89 respectively. The desorption results indicated that a higher concentration of $\mathrm{NaOH}$ is more favorable for attaining the better desorption percentage.

\section{CONCLUSION}

RPS was found to be an effective low-cost biosorbent for the removal of toxic hexavalent chromium from aqueous solution. Utilization of the biomaterial without any physical or chemical treatment is important from both environmental and economical viewpoints and is one of the important features of this study.

The main conclusions of the results obtained of $\mathrm{Cr}(\mathrm{VI})$ adsorption on RPS are summarized as follows:

The FTIR analyses showed presence of significantly functional groups on the RPS surface.

The optimum $\mathrm{pH}$ for maximum $\mathrm{Cr}(\mathrm{VI})$ removal was 2 , and the percentage removal of $\mathrm{Cr}(\mathrm{VI})$ at higher $\mathrm{pH}$ decreases dramatically.

Table 2

Constants of Langmuir and Freundlich for $\mathrm{Cr}(\mathrm{VI})$ adsorption on RPS

\begin{tabular}{ccccccc}
\hline & \multicolumn{3}{c}{ Langmuir isotherm } & \multicolumn{4}{c}{ Freundlich isotherm } \\
\hline $\mathrm{q}_{\mathrm{m}}$ & $\mathrm{K}_{\mathrm{L}}$ & $\mathrm{R}_{\mathrm{L}}$ & $\mathrm{R}^{2}$ & $\mathrm{n}$ & $\mathrm{K}_{\mathrm{F}}$ & $\mathrm{R}^{2}$ \\
$(\mathrm{mg} / \mathrm{g})$ & & & & & $(\mathrm{mg} / \mathrm{g})$ & 0.998 \\
23.256 & 0.636 & 0.0498 & 0.979 & 2.445 & 7.501 & \\
\hline
\end{tabular}

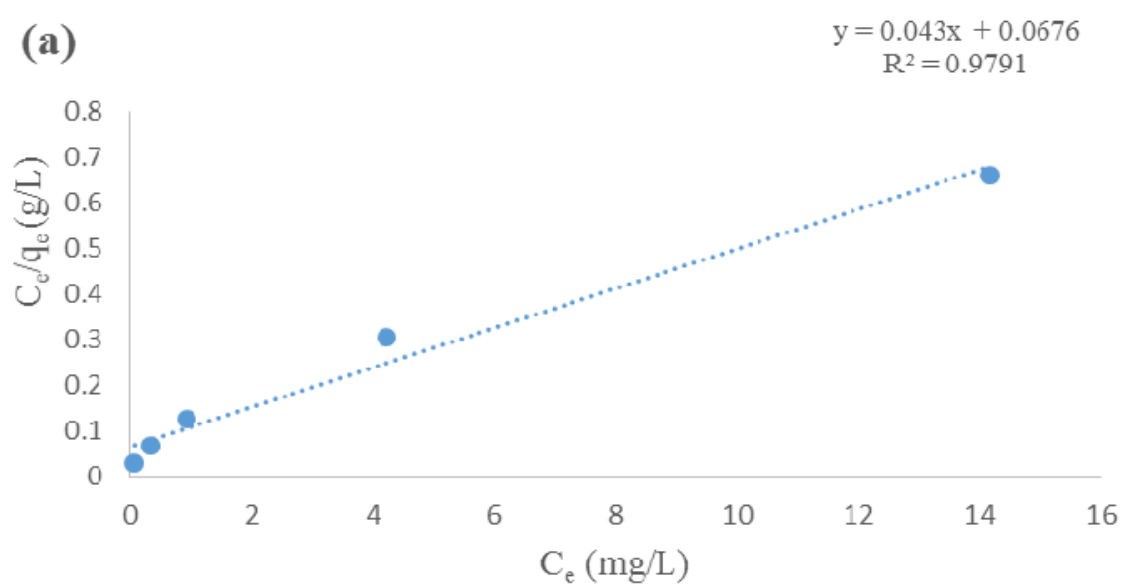

(b)



$\mathrm{R}^{2}=0.9984$



Fig. 9 - Plots of adsorption isotherms (a) Langmuir and (b) Freundlich. 


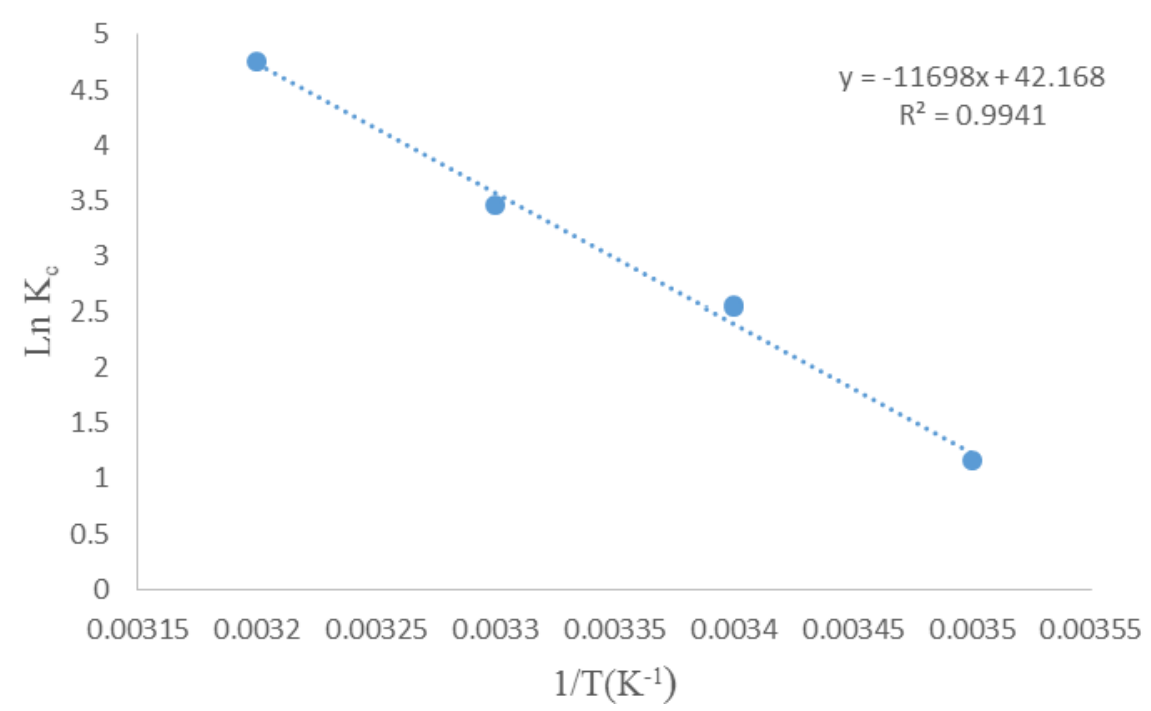

Fig. 10 - Plot of $\ln \mathrm{K}_{\mathrm{c}}$ versus $1 / \mathrm{T}$ for $\mathrm{Cr}(\mathrm{VI})$ adsorption on RPS.

Table 3

Thermodynamic parameter values for $\mathrm{Cr}(\mathrm{VI})$ adsorption on RPS

\begin{tabular}{|c|c|c|c|c|c|}
\hline $\mathrm{T}(\mathrm{K})$ & 283 & 293 & 303 & 313 & $\Delta \mathrm{H}\left(\mathrm{kJmol}^{-1}\right)=97.257$ \\
\hline$\Delta \mathrm{G}\left(\mathrm{kJmol}^{-1}\right)$ & -1.793 & -5.293 & -8.793 & -12.293 & $\Delta \mathrm{S}\left(\mathrm{kJmol}^{-1} \mathrm{~K}^{-1}\right)=0.350$ \\
\hline
\end{tabular}

The adsorption equilibrium was well explained by the Freundlich isotherm and the pseudo second order kinetics with satisfactory values of $\mathrm{R}^{2}$.

The negative $\Delta \mathrm{G}$ and the positive $\Delta \mathrm{H}$ indicated the spontaneous and endothermic nature of the $\mathrm{Cr}(\mathrm{VI})$ adsorption process onto investigated biosorbent.

The highest chemical regeneration percentage was obtained in alkaline conditions $(1 \mathrm{M} \mathrm{NaOH})$ and the RPS was recycled successfully.

Further, it can be concluded that RPS is a good potential, inexpensive and eco-friendly biosorbent for the removal of $\mathrm{Cr}(\mathrm{VI})$ from aqueous solution.

\section{REFERENCES}

1. S. Rangabhashiyam and N. Selvaraju, J. Mol. Liq., 2015, 209, 487-497.

2. S. Rangabhashiyam and N. Selvaraju, J. Mol. Liq., 2015, 207, 39 - 49 .

3. A. M. F. Orozco, E. M. Contreras and N. E. Zaritzky, J. Hazard. Mater., 2008, 150, 46-52.

4. J. Yang, M. Yu and T. Qju, J. Ind. Eng. Chem., 2014, 20, 480-486.

5. F. Z. Khelaifia, S. Hazourli, S. Nouacer, R. Hachani and M. Ziati, Int. Biodeterior. Biodegrad., 2016, 114, 76-86.

6. A. Ali, K. Saeed and F. Mabood, Alexandria. Eng. J., 2016, 55, 2933-2942.

7. WHO, 2nd edition, "Guidelines for Drinking Water Quality", vol. 1, World Health Organization, 1993, p. 2016.

8. M. S. Sivakami, T. Gomathi, J. Venkatesan, H. S. Jeong, S. K. Kim and P. N. Sudha, Int. J. Biol. Macromol.,2013, 57, 204-212.
9. J. B. Dima, C. Sequeiros and N. E. Zaritzky, Chemosphere., 2015, 141, 100-111.

10. S. Kuppusamy, T. Palanisami, M. Megharaj, K. Venkateswarlu, Y. Bok Lee and R. Naidu, Process Saf. Environ. Prot., 2016, 100,173-182.

11. V. K. Gupta and A. Rastogi, J. Hazard. Mater., 2009, 396-402.

12. S. C. Ponce, C. Prado, E. Pagano, F. E. Prado and M. Rosa, Ecol. Eng., 2015, 74, 33-41.

13. M. Elsay, Y. Menberu and R. S. Tesfaye, S. Afr. J. Chem., 2015, 68, 45-52.

14. S. S. Pillai, M. D. Mullassery, N. B. Fernandez, N. Girija, P. Geetha and M. Koshy, Ecotoxicol. Environ. Saf., 2013, 92, 199-205.

15. S. Marković, A. Stanković, Z. Lopičić, S. Lazarević, M. Stojanović and D. Uskoković, J. Environ. Chem. Eng., 2015, 3, 716-724.

16. M. Ziati, F. Khemmari, O. Cherifi, and F. Y. Didouche, Rev. Roum. Chim., 2017, 62, 865-874.

17. F. W. Gilcreas, M. J. Tarars and R. S. Ingols, "Standard Methods for the Examination of Water and Wastewater", 12th edition, American Public Health Association, Inc., New York, 1965, p. 213.

18. H. Deveci and Y. Kar, J. Ind. Eng. Chem., 2013, 19, 190-196.

19. D. Humelnicu, M. Ignat and F. Doroftei, Environ. Monit. Assess., 2015, 187- 222.

20. A. B. Wassie and V. C. Srivastava, J. Environ Chem. Eng., 2016, 4, 1117-1125.

21. M. A Wahab, S. Jellali and N. Jedidi, Bioresour.Technol., 2010, 101, 5070-5075.

22. G. Durán-Jiménez, V. Hernández-Montoya, M. A. Montes-Morán, A. Bonilla Petriciolet and N. A. RangelVázquez, Microporous. Mesoporous. Mater., 2014, 199, 99-107.

23. S. Á. Torrellas, R. G. Lovera, N. Escalona, C. Sepúlveda, J. L. Sotelo and J. García, Chem.Eng. J., 2015, 279, 788-798. 
24. M. Can, E. Bulut and M. Özacar, Ind. Eng. Chem. Res., 2012, 51, 6052-6063.

25. M. Can, E. Bulut, A. Örnek and M. Özacar, Chem. Eng. $J ., 2013,221,146-158$.

26. F. Mechati, C. Bouchelta, M. S. Medjram, R. Benrabaa and N. Ammouchi, J. Environ. Chem. Eng., 2015, 3, 1928-1938.

27. M. Kapur and M. K. Mondal, Chem. Eng. J., 2013, 218, 138-146.

28. S. S. Baral, S. N. Das and P. Rath, Biochem Eng j., 2006, 31, 216-22.

29. S. S. Baral, S. N. Das, G. R. Chaudhury and P. Rath, Adsorption., 2008, 14,111-21

30. N. R. Bishnoi, M. Bajaj, N. Sharma and A. Gupta, Bioresour. Technol., 2004, 91, 305-307.

31. M. Gueye, Y. Richardson, F. T. Kafack and J. Blin, J. Environ. Chem. Eng., 2014, 2, 273- 281.

32. A. K. Meena, G. K. Mishra, P. K. Rai, C. Rajagopal and P. N. Nagar, J. Hazard. Mater., 2008, 150, 474- 604.

33. R. Gottipati and S. Mishra, J. Ind. Eng. Chem., 2016, 36, 355-363.
34. K. K. Pandey, G. Prasad and V. N. Singh, Water Air Soil Pollut., 1986, 27, 287-296.

35. H. Ucun, Y. K. Bayhan and Y. Kaya, J. Hazard. Mater., 2008, 153, 52-59.

36. E. Malkoc and Y. Nuhoglu, Sep. Purif. Technol., 2007, 54, 291-298.

37. S. Lagergren, Handlingar, 1898, 24, 1-39.

38. Y. S. Ho and G. Mc Kay, Chem. Eng. J., 1998, 70, 115124.

39. L. Deng, G. Yang, J. Tao and J. Dai, J. Hazard. Mater., 2009, $166,1514-1521$.

40. Z. A. AL-Othman, R. Ali and Mu. Naushad, Chem. Eng. J., 2012, 184, 238-247.

41. I. Langmuir, J. Amer. Chem. Soc., 1916, 38, 2221-2295.

42. S. Yadav, V. Srivastava, S. Banerjee, C-H. Weng and Y. C. Sharma, Catena ., 2012, 100, 120-127.

43. T. W. Weber and R. K. Chackravorti, J. Am. Inst. Chem. Eng.1974, 20, 228-238.

44. H. M. F. Freundlich, J. Phys. Chem., 1906, 57, 385-470.

45. M. H. Dehghani, D. Sanaei, I. Ali and A. Bhatnagar, J. Mol. Liq., 2016, 215, 671-679. 
